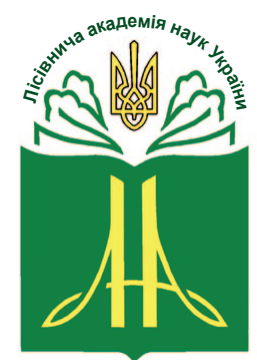

Forestry Academy of Sciences of Ukraine

Наукові праці Лісівничої академії наук України Proceedings of the Forestry Academy of Sciences of Ukraine

http://fasu.nltu.edu.ua

https://doi.org/10.15421/412022

Article received 2020.01.14

Article accepted 2020.12.28
ISSN 1991-606X print

ISSN 2616-5015 online

(a) $\triangle$ Correspondence author

Kateryna Davydenko

kateryna.davydenko74@gmail.com

Pushkinska str., 86, Kharkiv, 61024, Ukraine

UDC 630.4

\title{
Ophiostomatoid fungi vectored by bark beetles and colonizing trees of Pinus sylvestris in Sumy region (Ukraine)
}

\author{
K. Davydenko1', D. Baturkin²
}

Intensive mortality of Pinus sylvestris trees has recently been observed in the Sumy region in eastern Ukraine. There are two pine bark beetle species (Ips acuminatus and Ips sexdentatus), which spread resulted in considerable forest damage in Ukraine. The study of ophiostomatoid fungi vectored by bark beetles is very important to assess total harm of these insects.

Therefore, the aim of our research was i) to identify ophiostomatoid fungi associated with weakened and dying Scots pine trees infested by bark beetles in the Sumy region; ii) to test the pathogenicity of these ophiostomatoid fungi to evaluate their potential threat to Scots pine. The fungi were isolated from bark beetle galleries and identified based on morphological properties and DNA sequences.

In total, eight ophiostomatoid fungi (Graphium sp., Grosmannia sp.1, Ophiostoma bicolor, O. ips, O. canum, O. piceae, O. minus, Ophiostoma sp.1) were isolated from Scots pine trees infested by bark beetles. Scots pine seedlings were inoculated with eight fungi and sterile medium (control) to evaluate their pathogenicity. The inoculated seedlings were examined finally in 6 month after inoculation. Inoculation with O. minus produced significantly largest lesions and only this fungus caused mortality of pine seedlings. In total, all eight fungal species inoculated caused resin exudation and staining the bark around inoculations in Scots pine seedlings and five fungi caused different rate of seedlings decline. The size of stained sapwood was also greater following $O$. minus inoculations than other fungi or the control. All ophiostomatoid fungi caused significantly longer necrotic lesions and more occlusions in the sapwood than the controls.

Therefore, based on the ability of various ophiostomatoid fungi to weaken and kill pine seedlings and stain sapwood, O. minus was the most dangerous species for Scots pine trees, followed by Graphium sp. and Ophiostoma sp.1. The occurrence of ophiostmatoid fungi in the sapwood of Scots pine is consistent with the concept of their primary role in the colonization of the fresh sapwood of trees in the succession of microorganisms during wood decay.

Key words: ophiostomatoid fungi; Scots pine; bark beetles; pathogenicity; forest health.

Introduction. Climate change worldwide has been linked to increased mortality of conifers due to drought, water stress, and consequently associated insect outbreaks, especially bark beetles (Cottrell et al., 2020; Dobor et al., 2020).
Some bark beetles can cause extensive harm to the spruce and pine forests across Europe including Ukraine. Thus, massive mortality of Scots pine (Pinus sylvestris) trees has been observed in the Sumy region in northern Ukraine since 2016 due to the drought and

Kateryna Davydenko - Member of Forestry Academy of Sciences of Ukraine, PhD, (agricultural sciences), senior researcher, G. M. Vysotsky Ukrainian Research Institute of Forestry \& Forest Melioration, Pushkinska str., 86, Kharkiv, 61024, Ukraine; Visiting Researcherat Department of Forest Mycology and Plant Pathology, Uppsala BioCenter, Swedish University of Agricultural Sciences, P.O. Box 7026, SE-75007, Uppsala, Sweden. Tel.: +38-098-66-755-26. E-mail: kateryna.davydenko74@gmail.com ORCID http://orcid.org/0000-0001-6077-8533

2 Denys Baturkin - Head of Forest Protection Service «Kharkivlisozahyst», postgraduated student at G. M. Vysotsky Ukrainian Research Institute of Forestry \& Forest Melioration, Pushkinska str., 86. Tel.: +38-067 76481 07. E-mail: baturkin.denis@ukr.net ORCID https://orcid.org/00000002-6061-9863 
subsequent bark beetle outbreak. There are now two the most aggressive pine bark beetle, pine engraver beetle Ips acuminatus (Gyllenhal, 1827: Curculionidae, Scolytinae) and six-toothed bark beetle Ips sexdentatus (Boerner, 1766: Curculionidae, Scolytinae), the spread of which resulted in considerable damage of the forest in Ukraine last decade (Meshkova et al., 2018; Meshkova \& Borisenko, 2018). This complex of bark beetles is capable of killing pine forests over large areas in Ukraine and Europe (Meshkova et al., 2018). Moreover, bark beetles carry microbial spores on their exoskeleton, transferring them to trees during the colonization or feeding in the phloem of pine trees (Jankowiak, 2006; Bueno et al., 2010).

Therefore, now bark beetles are among the most economically and ecologically important pests of the world forests (Six, 2013; Cottrell et al., 2020;), but greater problems arise from their associated phytopathogenic blue-stain fungi, so-called ophiostomatoid fungi. This group includes genera such as Ophiostoma, Ceratocystiopsis, Graphilbum, Raffaelea and Leptographium in the Ophiostomatales, and Ceratocystis and Graphium in the Microascales (De Beer et al., 2013). The ophiostomatoid group contains a lot of tree pathogens, which are responsible for serious tree diseases, wood discoloration, and even high rates of tree mortality (Davydenko et al., 2017, 2019; Dori-Bachash et al., 2015; Repe et al., 2015). Many studies demonstrated that in the case of aggressive bark beetles that are able to kill healthy and slightly weakened trees, phytopathogenic fungi may help the beetles to overwhelm tree defenses (Six, 2003; Six, 2013; Wingfield et al., 2017).

There is only a little information about the association of ophiostomatoid fungi with bark beetles and their pathogenicity to pine trees in Ukraine (Davydenko et al., 2014; Davydenko et al., 2017). In a recent study in Ukraine, six blue-stain fungi, including, $O$. cf. rectangulosporium, $O$. ips $O$. minus, $O$. pallidulum, O. picea and O. olivaceum were isolated from the Ips acuminatus and their pathogenicity were tested (Davydenko et al., 2017, 2019). Among these, $O$. minus was the most pathogenic one when inoculated into $P$. sylvestris trees that it was also demonstrated in other studies (Jankowiak 2006; Jankowiak \& Bilański, 2012).

Therefore, the aim of our research was 1) to identify ophiostomatoid fungi associated with weakened and dying Scots pine trees infested by bark beetles in the Sumy region; 2) to test the pathogenicity of obtained ophiostomatoid fungi to broaden the knowledge and evaluate the potential threat of aforementioned fungal isolates, which could be harmful to Scots pine.

Material and methods. Field study and sample collection. In May 2017 and November 2018 to examine the presence of ophiostomatoid fungi, samples of blue-stained wood were taken from Scots pine trees damaged by bark beetles during sanitary felling in Sumy region: State Enterprise «Okhtyrske Forest Economy» (Okhtyrske FE), Okhtyrske forestry, compartment 52, subcompartment 3 and State Enterprise «Shostkinske
Forest Economy» (Shostkinske FE), Myronivske forestry, compartment 5, subcompartment 27. Sampling has been done from 28 randomly selected pine trees (14 trees in each site) which were 58-102 years old showing external signs of crown dieback and bark beetle attacks. Health condition (HC) of sampled trees was evaluated visually before cutting on a range of visual characteristics (crown color and density, dead branches in the crown, etc.) according to «Sanitary rules in the forests of Ukraine» (Санітарні правила в лісах України, 2016). Each tree was ranked according to one out of six categories (1st - healthy; 2nd - weakened; 3 rd - severely weakened; 4th - drying; 5 th - recently died; 6th - died over a year ago).

The two sites were approximately $256 \mathrm{~km}$ from each other. Samples were taken manually and the tool superficially sterilized with $96 \%$ ethanol after each sampling. Samples of the bark beetle galleries, phloem, and sapwood (approximately $5 \times 5 \mathrm{~cm}$ ) were stored in separate clean paper bags in the fridge in the laboratory.

Samples were inspected in the laboratory using a microscope for the presence of the fungal fruitbodies in the bark beetle galleries. Wood samples were sterilized by $96 \%$ ethanol for 15 seconds and small wood fragments were used to place on selective media for ophiostomatoid fungi ( $2 \%$ malt extract agar with cycloheximide $(200 \mathrm{mg} / \mathrm{L}$, AldrichSigma, St. Louis, Co. LLC.). Fungal cultures were purified by transferring growing hyphae or spore masses from individual colonies to new $2 \%$ malt extract agar without cycloheximide. Cultures were incubated at $22{ }^{\circ} \mathrm{C}$ in the dark. All cultures were grouped morphologically and identified using identification keys. Due to contradiction in the taxonomy of ophiostomatoid fungi, molecular methods (Davydenko et al., 2017) were also used to identify species.

DNA extraction, PCR, sequencing, and molecular identification. DNA was extracted from the cultures of the isolates representing morphological groups. Approximate DNA concentrations were determined at $260 \mathrm{~nm}$ using the Nano-drop 2000 spectrophotometer (Nano-drop Technologies, Wilmington, DE, USA). Internal transcribed spacer (ITS) regions 1 and 2, including the ribosomal 5.8S gene, were amplified using the ITS primer pairs (Davydenko et al., 2017). The reaction mixture contained, in a total volume of $15 \mu \mathrm{l}, 200 \mu \mathrm{M}$ deoxyribonucleotide triphosphates, $0,2 \mu \mathrm{M}$ of each primer, $0,03 \mathrm{U} / \mu 1$ Thermo Green Taq polymerase with reaction buffer Green, and $2,75 \mathrm{mM}$ final concentration of $\mathrm{MgCl} 2$. The thermal cycling was carried out using an Applied Biosystems GeneAmp PCR System 2700 thermal cycler (Foster City, CA, USA). An initial denaturation step at $95^{\circ} \mathrm{C}$ for 5 min was followed by 35 amplification cycles of denaturation at $95^{\circ} \mathrm{C}$ for $30 \mathrm{~s}$, annealing at $55^{\circ} \mathrm{C}$ for $30 \mathrm{~s}$, and extension at $72^{\circ} \mathrm{C}$ for $30 \mathrm{~s}$. The thermal cycling was ended by a final extension step at $72^{\circ} \mathrm{C}$ for $7 \mathrm{~min}$. The protein-coding gene $\beta$-tubulin (partial gene) was also amplified using the primers Bt2a and Bt2b (Davydenko et al., 2017).

Inoculation of pine seedlings. To investigate the pathogenicity of the ophiostomatoid fungi to 
P. sylvestris, inoculation experiments were carried out on 3-5-year-old seedlings of $P$. sylvestris, growing outdoor of laboratory «Kharkivlisozahyst». Stem diameters at the inoculation point were between $12,6 \mathrm{~mm}$ and $14,8 \mathrm{~mm}(13,7 \mathrm{~mm}$ on average $)$. All species from ophiostomatoid group were used in the pathogenicity test. In May 2019, 96 seedlings of $P$. sylvestris were inoculated with a spore suspension of selected fungal species (12 seedlings per fungus). All pine seedlings were inoculated by making a wound on the stem with the aid of a scalpel and pouring $10 \mu \mathrm{L}$ of spore solution suspension $\left(5 \times 10^{3}\right.$ spores $\left.\mathrm{mL}-1\right)$ onto the wound. The wound was then covered with a strip of Parafilm to prevent desiccation. In addition, 12 control seedlings were inoculated in the same way, with sterilized water, and the wounds were also covered with a strip of Parafilm. The morphological condition of all pine seedlings was first evaluated on a weekly, and then a monthly basis as visually healthy, weakened, or dead plants subject to typical symptoms of dampingoff, crown decline, resin flow, and necrosis. Disease susceptibility was finally estimated at 120 and 180 days post-inoculation. After this, all plants were harvested and the bark of each seedling was peeled off the stem and the sizes of any lesions (length, depth, and width) that had formed in the phloem around the inoculation points were measured. The stems were then cut across the inoculation points. The tangential width and radial length (depth) of discoloured zones of sapwood were measured on the surface of the cross-section. Small pieces of wood were cut from the discoloured sapwood of the seedlings and transferred onto $2 \%$ malt extract agar with $0.8 \%$ cyclohexamide and $0.2 \%$ streptomycin sulphate (CSMA) to confirm the presence of the inoculated fungus.

Statistical analyses. Raw sequence data were analyzed using the SeqMan Pro version 10.0 software from DNASTAR package (DNASTAR, Madison, WI, USA). Databases at GenBank and at the Department of Forest Mycology and Plant Pathology, Swedish University of Agricultural Sciences, were used to determine the identity of ITS rRNA sequences. The criteria used for identification were: sequence coverage $>80 \%$; similarity to taxon level $98-100 \%$, similarity to genus level 92-97\%.
A NCBI BLAST (National Centre for Biotechnology Information, www.ncbi.nlm.nih.gov) search was run with the edited sequences for preliminary species identification. Obtained data were analyzed using Kolmogorov-Smirnov test to check the normal distribution and homogeneity of variance. Data on lesion size of Scots pine seedlings inoculated with fungal species were analyzed using ANOVA general linear model $(\mathrm{GLM})$ in Statistica software (STATISTICA ${ }^{\circledR} 7.0$ (StatSoft, Inc., Tulsa, USA). Necroses were measured in only one direction from the point of inoculation. For ANOVA significant effects $(\mathrm{p}<0,05)$, a post hoc HSD Tukey test was used to compare the means with a significance level of $p<0,05$.

Results and discussion. Healthy, weakened, and dying Scots pine trees in both sites were inspected and visually evaluated to rank. The signs of bark beetle attack and typical symptoms of the presence of ophiostomatoid fungi (blue to greyish-black stains on wood) were observed only in trees of the $3^{\text {rd }}-5^{\text {th }}$ categories of health condition (severely weakened, drying, and recently died respectively) (Fig. 1).

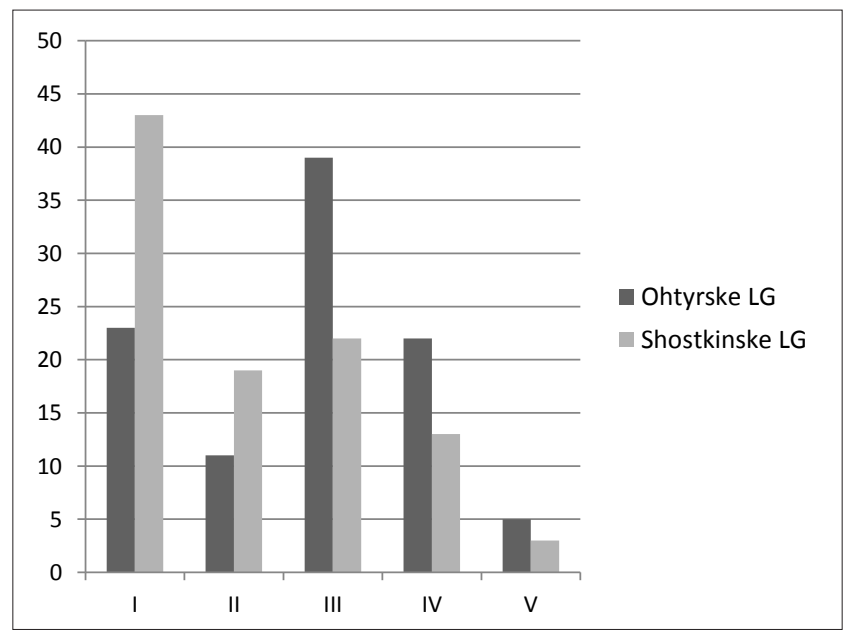

Fig. 1. The number of Scots pine trees of different health condition (HC)

Moreover, almost all trees in the $3^{\text {rd }}-5^{\text {th }}$ categories were damaged by bark beetles and ophiostomatoid fungi for both sites (Fig.2).

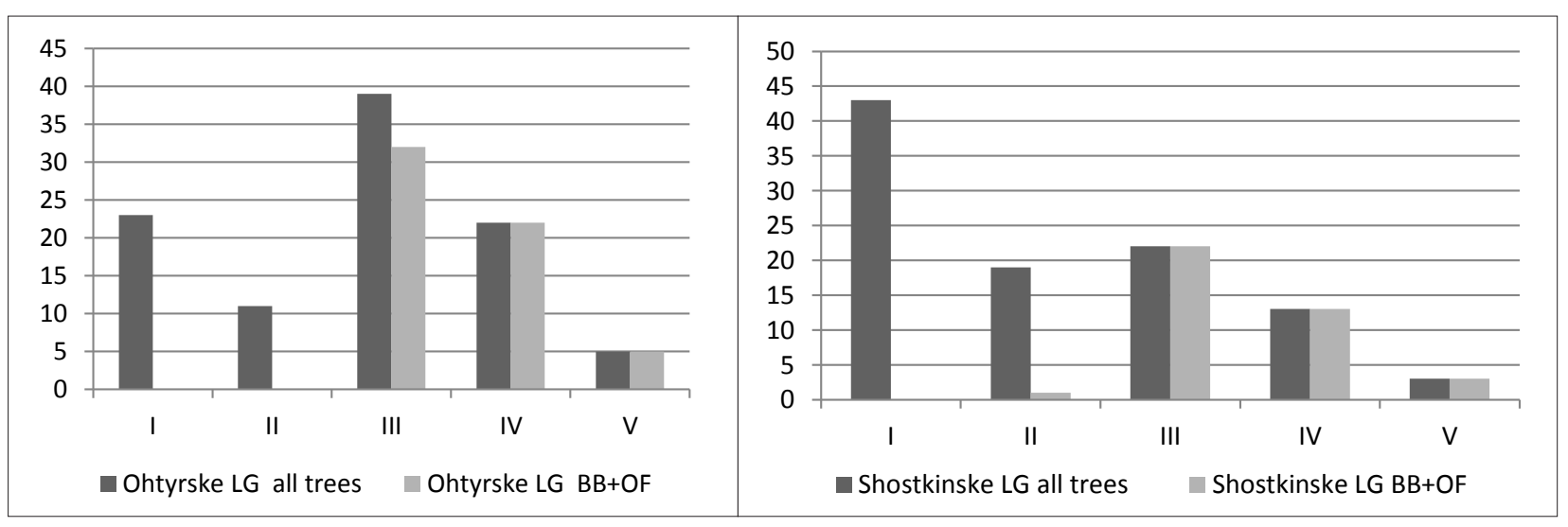

Fig. 2. The number of Scots pine trees of different forest health condition damaged by bark beetles (BB) and ophiostomatoid fungi (OF) for Ohryrske FE (left) and Shostkinske FE (right) 
In total, 256 isolates were obtained from wood samples which further were grouped in 8 clusters (Tab. 1). The isolates were used for DNA extractions, species identification, and further inoculation.

The most commonly for all trees at both sites was Ophiostoma piceae (82.1\%), the slightly less abundant were Ophiostoma ips and O. minus (67.9\%), as well as Ophiostoma bicolor (64.3\%), (data not shown). The frequency of other detected species was lower than $30 \%$. The five from eight blue-stain fungi (Ophiostoma bicolor, O. ips, O. canum, O. piceae, O. minus) were isolated from trees 3rd and 4th health categories at both sites. Graphium sp was found only on severely weakened trees at Shostkinske FE, while Grosmannia sp. 1 was also isolated only from trees of 4th category of FHC but for both sites (see Tab. 1).

Table 1

Frequency of ophiostomatoid fungi from weakened Pinus sylvestris trees grown in Sumy region in Ukraine

\begin{tabular}{lcccc}
\hline \multirow{2}{*}{ Ophiosomatoid species } & \multicolumn{3}{c}{ Frequency of isolates from galleries } \\
\cline { 2 - 5 } & \multicolumn{2}{c}{ Okhtyrske FE } & \multicolumn{2}{c}{ Shostkinske FE } \\
\cline { 2 - 5 } & HCI=3 & HCI=4 & HCI=3 & HCI=4 \\
\hline Grosmannia sp.1 & - & 21.43 & - & 55.71 \\
Graphium sp. & - & - & 21.43 & 57.00 \\
Ophiostoma bicolor R. W. Davidson \& D. E. Wells & 14.29 & 35.71 & 14.29 & 28.57 \\
Ophiostoma canum (Münch) Syd. \& P. Syd & 7.14 & 14.29 & 28.57 & 50.00 \\
Ophiostoma ips (Rumbold) Nannfeldt & 28.57 & 28.57 & 35.71 & 57.14 \\
Ophiostoma minus (Hedgc.) Syd. \& P. Syd & 28.57 & 14.29 & 28.57 & 64.29 \\
Ophiostoma piceae (Münch) Sydow \& P. Sydow & 21.43 & 50.00 & - & - \\
Ophiostoma sp.1 & 14.29 & 28.57 & & - \\
\hline
\end{tabular}

The principal components analysis (PCA) based on Euclidean distances revealed that the first principal component explained $97.42 \%$ of the variability in the data of the fungal communities (data not shown). Four different clusters were formed for all sites in the respect to the fungal community compositions, indicating the significant difference between sites caused blue-stain fungal community shifts associated with bark beetles' galleries and the similarity between the trees of the 3rd and 4th health condition categories (see Fig. 2).

The similarity matrices between tree categories and the difference between site groups were employed to yield different results. In this work, a similarity matrix based upon Euclidean distance, commonly used in cluster analysis, is developed as a viable alternative. This analysis resulted in Euclidean similarity-based PCA identifies parameters that are close to each other, thereby providing a wide range of similarity between fungal communities for trees 3rd and 4th $\mathrm{HC}$ measures available to investigators, to be chosen based on what characteristic they wish to identify. Moreover, the correspondence analysis revealed associations between fungal taxa and different types of samples (Fig. 3).

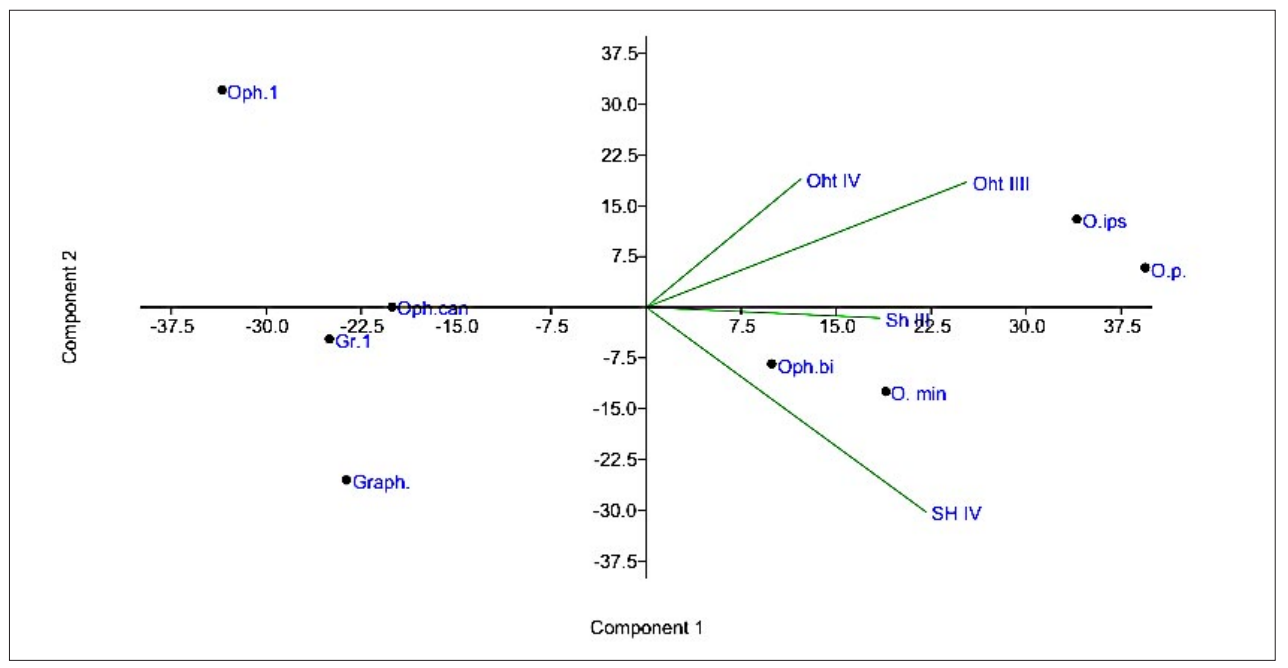

Fig. 3. Principal components analysis showing an association between different fungal species and individual samples of this study: trees of 3rd and 4th categories at Okhtyrske FE (Oht III and Oht IV) and Shostkinske FE at Shostkinske FE (Sh III and SH IV) Taxonomic names correspond to a position in the ordination (centered) and their font size corresponds to a relative abundance as indicated in the upper right corner of the diagram and Table 1

(Gr.1 - Grosmannia sp.1, Graph. - Graphium sp., Oph.bi - Ophiostoma bicolor, Oph.can - Ophiostoma canum, O.ips -

Ophiostoma ips, O. min - Ophiostoma minus, O.p. - Ophiostoma piceae, Oph.1 - Ophiostoma sp.1). 
Ophiostoma ips and $O$. piceae were commonly associated with the pine trees from Okhtyrske FE while Ophiostoma bicolor and $O$. minus were commonly linked to the pine trees 3rd and 4th FHC from Shostkynske FE. Another group of fungi including Grosmannia and Ophiostoma canum were associated with all groups while Graphium sp. and Ophiostoma sp.1 were distributed more or less randomly and did not show a clear association with any type of sample (see Fig. 3).

Pathogenicity test. As mentioned in the introduction, some ophiostomatoid fungi are pathogenic to their host plants. Generally, ophiostomatoid fungi are introduced to their host plants through wounds produced by bark beetles feeding and gallery construction. The introduction and spread of ophiostomatoid fungi under the bark result in the necrotic lesions in the phloem around bark beetle galleries, sapwood colonization, and further, sometimes, tree decline or death. Therefore, artificial inoculation and further observation of emerged symptoms is the main criterion to determine the pathogen of particular plant disease. Therefore, the virulence of the ophiostomatoid fungi was evaluated by measuring the lesions and monitoring the mortality of Scots pine seedlings after inoculation for 6 months.

The inoculated seedlings were harvested after inoculation, and the size of the lesions formed in the inner bark around the inoculation points together with the sizes of the stained and dried zones of sapwood were measured. The necrotic lesions formed around the inoculation points on the inner bark spread mainly longitudinally and only slightly in the tangential direction. The lengths of lesions differ according to the fungus inoculated. Additionally, a wedge-shaped dry zone of sapwood with or without blue staining spreads from the inoculation point toward the border between the sapwood and heartwood. The fungi produced larger lesions and were more virulent. The ability of the fungi to colonize sapwood and disturb water transportation is important for evaluating their ability to kill host trees (Solheim, 1992, Yamaoka et al., 2000). Some ophiostomatoid fungi associated with bark beetles have the ability to kill their host trees; e.g., Endoconidiophora polonica associated with I. typographus (Solheim, 1992) and Grosmannia clavigera with Dendroctonus ponderosae (Yamaoka et al. 2000).

In our study, all isolated ophiostomatoid fungi were tested to check their ability to infect seedlings of $P$. sylvestris. Most of the pathogenicity results were generally concur with previously described inoculation experiments, thereby demonstrating similar lesion morphology and similar patterns of plant tissue colonization by different ophiostomatoid fungal species (Jankowiak \& Bilanski, 2013; Solheim, 1992). However, a few isolates, such as Graphium sp., Grosmania sp., Ophiostoma sp., were tested first in our study. Ophiostomatoid fungi associated with Ips acuminatus and Hylurgus ligniperda infesting Scots pine in Ukraine were reported by Davydenko (2014, 2017). Revised information for these fungi together with unpublished data are shown in Table 2. Therefore, one species of Grosmannia and one species of Graphium were isolated from bark beetle galleries on infesting Scots pine.

According to our results, $O$. minus was much more pathogenic than other fungi based on all criteria of fungal pathogenicity. It was the only fungus that caused the highest rate of sapwood desiccation and mortality of $16.7 \%$ of seedlings in 6 months (see Tab. 2). $O$. minus caused dieback of $P$. sylvestris seedlings, which also demonstrated in previous studies (Solheim 1992; Jankowiak, 2006). Most of the studies focused on pathogenicity ophiostomatoid fungi indicated that the ability to invade sapwood and phloem can be considered as critical for pathogenic colonization (Solheim, 1992; Linnakoski et al. 2012).

All eight fungal species inoculated caused resin exudation and staining on the bark around inoculations in Scots pine seedlings. The isolate of $O$. minus showed the highest growth in all directions, with statistical significance $(\mathrm{P}<0.00147)$, although in the radial direction the growth was similar to Graphium sp. and in the tangential direction was similar to O. bicolor (see Tab. 2). This species produced a black discoloration of the wood and caused the greatest stained area ( $\mathrm{P}<0.001)$, as measured on cross-sections.

Effect of inoculation of Pinus sylvestris seedlings with ophiostomatoid fungi*

Table 2

\begin{tabular}{|c|c|c|c|c|c|c|}
\hline \multirow[b]{2}{*}{ Species } & \multicolumn{3}{|c|}{ Phloem necrosis, $\mathrm{mm}^{* *}$} & \multirow[b]{2}{*}{$\begin{array}{l}\text { Resin } \\
\text { flow, \% }\end{array}$} & \multirow[b]{2}{*}{$\begin{array}{l}\text { Declining } \\
\text { plants, \% }\end{array}$} & \multirow[b]{2}{*}{$\begin{array}{c}\text { Dead } \\
\text { plants, } \%\end{array}$} \\
\hline & Length & Width & $\begin{array}{l}\text { Depth of } \\
\text { blue-stain }\end{array}$ & & & \\
\hline 1 & 2 & 3 & 4 & 5 & 6 & 7 \\
\hline Grosmannia sp.1 & $13.24 \pm 0.22^{\mathrm{e}}$ & $2.42 \pm 0.4^{b}$ & $1.29 \pm 0.4^{\mathrm{b}}$ & 75.00 & 16.67 & 0.00 \\
\hline Graphium sp. & $19.86 \pm 0.12^{\mathrm{d}}$ & $3.24 \pm 0.6^{\mathrm{c}}$ & $1.62 \pm 0.4^{\mathrm{b}}$ & 33.33 & 41.67 & 0.00 \\
\hline $\begin{array}{l}\text { Ophiostoma ips (Rumbold) } \\
\text { Nannfeldt }\end{array}$ & $4.52 \pm 0.15^{\mathrm{c}}$ & $2.58 \pm 0.2^{\mathrm{b}}$ & $0.21 \pm 0.2^{\mathrm{a}}$ & 25.00 & 0.00 & 0.00 \\
\hline $\begin{array}{l}\text { Ophiostoma minus (Hedgc.) } \\
\text { Syd. \& P. Syd d }\end{array}$ & $42.56 \pm 0.1^{\mathrm{d}}$ & $6.62 \pm 1.1^{\mathrm{e}}$ & $1.65 \pm 0.4^{\mathrm{b}}$ & 91.67 & 41.67 & 16.67 \\
\hline
\end{tabular}


Continuation of Table 2

\begin{tabular}{|c|c|c|c|c|c|c|}
\hline 1 & 2 & 3 & 4 & 5 & 6 & 7 \\
\hline $\begin{array}{l}\text { Ophiostoma bicolor } \\
\text { R. W. Davidson \& D. E. Wells }\end{array}$ & $6.25 \pm 0.95^{\mathrm{c}}$ & $4.42 \pm 1.2^{\mathrm{d}}$ & $0.20 \pm 0.4^{\mathrm{a}}$ & 41.67 & 0.00 & 0.00 \\
\hline $\begin{array}{l}\text { Ophiostoma piceae (Münch) } \\
\text { Sydow \& P. Sydow }\end{array}$ & $4.21 \pm 0.04^{\mathrm{c}}$ & $2.17 \pm 0.9^{b}$ & $0.20 \pm 0.4^{\mathrm{a}}$ & 33.33 & 8.33 & 0.00 \\
\hline $\begin{array}{l}\text { Ophiostoma canum (Münch) } \\
\text { Syd. \& P. Syd }\end{array}$ & $2.92 \pm 0.06^{\mathrm{b}}$ & $2.15 \pm 1.3^{\mathrm{b}}$ & $0.00 \pm 0.0^{\mathrm{a}}$ & 33.33 & 16.67 & 0.00 \\
\hline Ophiostoma sp.1 & $8.56 \pm 1.52^{\mathrm{c}}$ & $4.17 \pm 0.2^{\mathrm{c}}$ & $0.20 \pm 0.4^{b}$ & 58.33 & 33.33 & 0.00 \\
\hline Control & $1.20 \pm 0.02^{\mathrm{a}}$ & $1.10 \pm 0.1^{\mathrm{a}}$ & $0.00 \pm 0.0^{\mathrm{a}}$ & 0.00 & 0.00 & 0.00 \\
\hline $\mathrm{F}_{\text {fact }}$ & 24.56 & 32.25 & 124.24 & 95.23 & 125.21 & 32.21 \\
\hline $\mathrm{P}$ & 0.0001 & 0.0001 & 0.0001 & 0.0001 & 0.005 & 0.005 \\
\hline
\end{tabular}

The second fastest-growing fungal species in all directions was Graphium sp. This species caused a grey stain on the wood and decline $41.7 \%$ of pine seedlings as well as $O$. bicolor (see Tab. 2). Grosmannia sp.1 grew at a similar radial rate to Graphium sp. but grew more slowly both tangentially and especially longitudinally. Ophiostoma sp. 1 caused the decline of $33 \%$ pine seedlings and grew significantly $(\mathrm{P}<0.001)$ more slowly than Graphium sp. Ophiostoma canum and O. piceae caused significant less decline of pine seedlings and grew much more slowly than above-mentioned ophiostoma fungi $(16.67$ and $8.33 \%$ respectively, $\mathrm{P}<0.001$ ) while $O$. bicolor and $O$. ips did not caused seedling decline at all during 6 months (see Tab. 2), although caused staining on the bark around inoculations in all directions significantly more than control inoculations $(\mathrm{P}<0.001)$. O. ips and O. piceae penetrated the smallest areas of the wood caused a light greyish discoloration compared to the other species $(\mathrm{P}<0.05)$.

The inoculated fungi were successfully re-isolated from $98 \%$ of the inoculation points. No ophiostomatoid species were isolated from the control trees.

Conclusions. Based on the ability of tree declining, killing and wood staining, O. minus is the most important species on Scots pine trees, followed by Graphium sp. and Ophiostoma sp.1. The ophiostomatoid fungi isolated in this study are commonly found to be associated with bark beetles and detected on conifer timber (Linnakoski et al., 2012). The occurrence of ophiostmatoid species in the sapwood of Scots pine is consistent with the concept the ophiostomatoid fungi are primary colonizers of the fresh sapwood of trees and timber and other wood in the succession of microorganisms during wood decay (Solheim, 1992).

\section{Список літератури}

Санітарні правила в лісах Украӥни (2016): у редакції постанови Кабінету Міністрів України від 26 жовтня 2016 р. № 756 [Sanitary Forests Regulations in Ukraine (2016). In the redaction of Decree of Cabinet Minister of Ukraine from 26 October 2016, № 756 (in Ukrainian)]. Retrieved from https://zakon.rada.gov. ua/laws/show/555-95-п

Bueno, A., Diez, J.J., \& Fernandez, M.M. (2010). Ophiostomatoid Fungi Transported by Ips sexdentatus (Coleoptera, Scolytidae) in Pinus pinaster in NW Spain. Silva Fennica, 44 (3), 387-397. https://doi. org/10.14214/sf.137

Cottrell, S., Mattor, K.M., Morris, J.L., Fettle, C.J., McGrady, P., Maguire, D., ...Roberts, R. (2020). Adaptive capacity in social-ecological systems: a framework for addressing bark beetle disturbances in natural resource management. Sustainability Science, 15 (2), 555-567. https://doi.org/10.1007/s11625-01900736-2

Davydenko, K. (2019). A comparative characteristic of fungal communities associated with Ips acuminatus in different regions of Ukraine. Наукові праиi Лісівничої академї наук України, 18, 118-128. https://doi.org/10.15421/411912

Davydenko, K., Vasaitis, R., \& Menkis, A. (2017). Fungi associated with Ips acuminatus (Coleoptera: Curculionidae) in Ukraine with a special emphasis on pathogenicity of ophiostomatoid species. European Journal of Entomology, 114, 77-85. https://doi. org/10.14411/eje.2017.011

Davydenko, K., Vasaitis, R., Meshkova, V., \& Menkis, A. (2014). Fungi associated with the red-haired bark beetle, Hylurgus ligniperda (Coleoptera: Curculionidae) in the forest-steppe zone in eastern Ukraine. European Journal of Entomology, 111 (4), 561-565. Retrieved from https://search.proquest. com/docview/1622264211? accountid $=28676$

De Beer, Z. W., Seifert, K., \& Wingfield, M. (2013). A nomenclator for ophiostomatoid genera and species in the Ophiostomatales and Microascales. The ophiostomatoid fungi: expanding frontiers 12, 245322. Retrieved from https://www.fungaltaxonomy. 
org/files/6914/0613/2818/deBeeretal.2013. OphioNomenclator.pdf

Dobor, L., Hlasny, T., Rammer, W., Zimova, S., Barka, I., \& Seidl, R. (2020). Spatial configuration matters when removing windfelled trees to manage bark beetle disturbances in Central European forest landscapes. Journal of Environmental Management, 254. https://doi.org/10.1016/j.jenvman.2019.109792

Dori-Bachash, M., Avrahami-Moyal, L., Protasov, A., Mendel, Z., \& Freeman, S. (2015). The occurrence and pathogenicity of Geosmithia spp. and common blue-stain fungi associated with pine bark beetles in planted forests in Israel. European Journal of Plant Pathology, 143 (4), 627-639. https://doi.org/10.1007/ s10658-015-0713-9

Jankowiak, R. (2006). Fungi associated with Tomicus piniperda in Poland and assessment of their virulence using Scots pine seedlings. Annals of Forest Science, 63 (7), 801-808. https://doi.org/10.1051/ forest:2006063

Jankowiak, R., \& Bilański, P. (2013). Diversity of ophiostomatoid fungi associated with the large pine weevil, Hylobius abietis and infested scots pine seedlings in Poland. Annals of Forest Science, 70 (4), 391-402. https://doi.org/10.1007/s13595-0130266-z

Linnakoski R., De Beer Z.W., Duong T.A., Niemela P., Pappinen A., \& Wingfield M. J. (2012). Grosmannia and Leptographium spp. associated with coniferinfesting bark beetles in Finland and Russia, including Leptographium taigense sp. nov Antonie van Leeuwenhoek, 102 (2012), pp. 375-399. https:// doi.org/10.1007/s10482-012-9747-6

Meshkova, V.L., \& Borysenko, O.I. (2018). Prediction for bark beetles caused desiccation of pine stands. Лісівниитво $i$ агролісомеліораиія, 132, 155-161. https://doi.org/10.33220/10263365.132.2018.155

Meshkova, V. L., Borysenko, O. I., \& Pryhornytskyi, V. I. (2018). Forest site conditions and other features of Scots pine stands favorable for bark beetles. Наукові праиі Лісівничої академії наук України, 16, 106114. https://doi.org/10.15421/411812

Repe, A., Bojovic, S., \& Jurc, M. (2015). Pathogenicity of ophiostomatoid fungi on Picea abies in Slovenia. Forest Pathology, 45 (4), 290-297. https://doi. org/10.1111/efp.12170

Six, D.L. (2003). A comparison of mycangial and phoretic fungi of individual mountain pine beetles. Canadian Journal of Forest Research-Revue Canadienne De Recherche Forestiere, 33 (7), 13311334. https://doi.org/10.1139/x11-041

Six, D.L. (2013). The Bark Beetle Holobiont: Why Microbes Matter. Journal of Chemical Ecology, 39 (7), 989-1002. https://doi.org/10.1007/s10886-0130318-8

Solheim, H. (1992). The early stages of fungal invasion in Norway spruce infested by the bark beetle Ips typographus. Canadian Journal of Botany, 70, 1-5. https://doi.org/10.1139/b92-001
Wingfield, M.J., Barnes, I., de Beer, Z.W., Roux, J., Wingfield, B.D., \& Taerum, S.J. (2017). Novel associations between ophiostomatoid fungi, insects and tree hosts: current status-future prospects. Biological Invasions, 19 (11), 3215-3228. https://doi. org/10.1007/s10530-017-1468-3

Yamaoka, Y., Takahashi, I., \& Iguchi K. (2000). Virulence of ophiostomatoid fungi associated with the spruce bark beetle Ips typographus f. japonicus in Yezo spruce. Journal of Forest Research, 5, 87-94. https://doi.org/10.1007/BF02762525

\section{Офіостомові гриби, які пов'язані 3 короїдами та заселяють Pinus sylvestris у Сумській області (Україна)}

\section{К. В. Давиденко', Д. О. Батуркін²}

Останнім часом у східному регіоні України, зокрема в Сумській обл., відбувається інтенсивне всихання соснових лісів. Соснові насадження сильно пошкоджують переважно два види короїдів - Ips acuminatus та Ips sexdentatus. Офіостомові гриби, яких переносять короїди, можуть значно посилювати загальну шкоду лісам від цих комах, що необхідно брати до уваги під час оцінювання загальних збитків від короїдів.

Метою дослідження було виявити видовий склад офіостомових грибів, пов'язаних із сильно ослабленими та всихаючими деревами сосни звичайної у Сумській обл., оцінити патогенність офіостомових грибів і встановити потенційну загрозу для Pinus sylvestris L.

Офіостомові гриби виділені з личинкових ходів короїдів та ідентифіковані до рівня виду або роду на основі морфологічних особливостей та аналізу ITS послідовностей ДНК.

Загалом виділено вісім видів офіостомових грибів (Graphium sp., Grosmannia sp.1, Ophiostoma bicolor, O. ips, O. canum, O. piceae, O. minus, Ophiostoma sp.1). Саджанці Pinus sylvestris іноку-

Давиденко Катерина Валеріївна - член-кореспондент Лісівничої академії наук України, кандидат сільськогосподарських наук, старший науковий співробітник. Український науководослідний інститут лісового господарства та агролісомеліорації ім. Г.М. Висоцького, вул. Пушкінська, 86, Харків, 61024, Україна; Запрошений науковий співробітник Департаменту Лісової мікології і фітопатології Шведського Аграрного Університету, Р.О. Вох 7026, SE-75007, Уппсала, Швеція. Тел.: +38-09866755 26. E-mail: kateryna.davydenko74@gmail.com ORCID http://orcid.org/0000-0001-6077-8533

Батуркін Денис Олександрович - директор Державного спеціалізованого лісозахисного підприємства «Харківлісозахист», Харківська обл., смт. Покотилівка, вул. Незалежності 127,62458 , Україна; аспірант Українського науково-дослідного інституту лісового господарства та агролісомеліорації ім. Г.М. Висоцького, вул. Пушкінська, 86, Харків, 61024, Україна. Tel.: +38-067 76481 07. E-mail: baturkin.denis@ukr.net ORCID https://orcid.org/0000-0002-6061-9863 
льовані вісьмома ізолятами грибів і стерильним середовищем (контроль) для оцінювання їхньої патогенності. Інокульовані рослини оглядали впродовж шести місяців, оцінюючи їхній загальний стан, розмір некрозів, смолові патьоки. Інокуляція саджанців грибом $O$. minus спричинила найбільше ураження і навіть загибель саджанців сосни. Загалом, у варіантах інокуляції всіх восьми видів грибів визначено ексудацію смоли та знебарвлення кори навколо місця інокуляції. Серед цих грибів п’ять видів спричинили ослаблення саджанців. Площа знебарвлення флоеми була достовірно найбільшою після інокуляції саджанців грибом O. minus. Всі види офіостомових грибів спричиняли значно довші некротичні ураження саджанців, порівняно 3 контролем.

За результатами дослідження, у зв'язку зі спроможністю спричиняти всихання й загибель рослин сосни та знебарвлення їхньої деревини, гриб O. minus варто вважати найнебезпечнішим патогеном соснових саджанців. Менш вірулентними видами є Graphium sp. та Ophiostoma sp.1. Факт заселення всихаючих дерев сосни офіостомовими грибами узгоджується 3 концепцією, що вони є первинними колонізаторами свіжої деревини під час процесу іiі руйнування.

Ключові слова: офіостомові гриби; сосна звичайна; короїди; патогенез; санітарний стан лісу.

\section{Офиостомовые грибы, переносимые короедами и заселяющие Pinus sylvestris в Сумской области (Украина)}

\section{Е. В. Давиденко ${ }^{1}$, Д. А. Батуркин ${ }^{2}$}

В последнее время в восточном регионе Украины, в частности в Сумской обл., происходит интенсивное усыхание сосновых лесов. Сосновые насажде-

\footnotetext{
Давиденко Екатерина Валерьевна - член-корреспондент Лесной академии наук Украины, кандидат сельскохозяйственных наук, старший научный сотрудник. Украинский научно-исследовательский институт лесного хозяйства и агролесомелиорации им. Г.Н. Высоцкого, ул. Пушкинская, 86, Харьков, 61024, Украина. Приглашенный научный сотрудник Департамента Лесной микологии и фитопатологии Шведского Аграрного Университета, Р.О. Вох 7026, SE-75007, Уппсала, Швеция. Тел .:+38-09866755 26. E-mail: kateryna.davydenko74@ gmail.com ORCID http://orcid.org/0000-0001-6077-8533

Батуркин Денис Александрович - директор Государственного специализированного лесозащитного предприятия «Харьковлесозащита», Харковськая обл., пгт. Покотиловка, ул. Незалежности 127, 62458, Украина; аспирант Украинского научноисследовательского института лесного хозяйства и агролесомелиорации им. Г.Н. Высоцкого, ул. Пушкинская, 86, Харьков, 61024, Украина. Tel.: +38-067 76481 07. E-mail: baturkin. denis@ukr.net ORCID https://orcid.org/0000-0002-6061-9863
}

ния сильно повреждают в основном два вида - Ips acuminatus и Ips sexdentatus. Офиостомовые грибы, которых переносят короеды, могут заметно усиливать общую вредоносность этих насекомых, что необходимо принимать во внимание при оценке общего ущерба от короедов.

Целью исследования было выявить видовой состав офиостомовых грибов, связанных с сильно ослабленными и усыхающими деревьями сосны в Сумской обл., оценить патогенность офиостомовых грибов и потенциальную угрозу для Pinus sylvestris.

Офиостомовые грибы выделены из личиночных ходов короедов и определены до уровня вида или рода с помощью микроскопа по морфологическим особенностям, а также с помощью молекулярного метода, используя анализ ITS последовательностей ДНК.

Всего выделено восемь видов офиостомовых грибов (Graphium sp., Grosmannia sp.1, Ophiostoma bicolor, O. ips, O. canum, O. piceae, O. minus, Ophiostoma sp.1). Саженцы Pinus sylvestris инокулированы восемью видами выделенных грибов и стерильной средой в качестве контроля для оценки их патогенности. Инокулированные растения осматривали в течение шести месяцев, оценивая общее состояние растений, размер некрозов, потеки смолы. Инокуляция саженцев грибом O. minus привела к наиболее интенсивным поражениям и даже гибели сосновых саженцев. Все восемь видов грибов вызвали экссудацию смолы и обесцвечивание коры вокруг места инокуляции. Пять видов грибов вызвали ослабление саженцев в той или иной степени. Площадь обесцвечивания флоэмы также была достоверно большей у растений, инокулированных грибом O. minus. Все офиостомовые грибы вызывали некрозы древесины большего размера по сравнению с контролем.

По результатам исследования, в связи со способностью вызвать усыхание и гибель растений, обесцвечивание древесины гриб O. minus следует считать самым опасным патогеном сосновых саженцев. Менее вирулентными видами оказались Graphium sp. и Ophiostoma sp.1. Факт заселения усыхающих деревьев сосны офиостомовыми грибами согласуется с концепцией, что они являются первичными колонизаторами свежей древесины в процессе ее разрушения.

Ключевые слова: офиостомовые грибы; сосна обыкновенная; короеды; патогенез; санитарное состояние леса. 